\title{
Paracrine interactions between platelet-activating factor and prostaglandins in hormonally-treated human luteal phase endometrium in vitro*
}

\author{
A. A. Alecozay†, M. J. K. Harper $\dagger$, R. S. Schenken $\dagger$ and D. J. Hanahan $\ddagger$ \\ Department of $†$ Obstetrics and Gynecology, and of $\ddagger$ Biochemistry, University of Texas \\ Health Science Center, San Antonio, TX 78284-7836, USA
}

Summary. Stromal cells and epithelial glands were separated after enzymic digestion of specimens obtained from 27 women at hysterectomy or endometrial biopsy during the luteal phase, and then cultured to confluence in vitro. PGE release into the culture medium (mean \pm s.e.m.: $\mathrm{ng} / \mathrm{mg}$ protein $/ 24 \mathrm{~h}$ ) from gland cell cultures was not changed by oestradiol $(17.6 \pm 1.3$ for control and $25.5 \pm 2.8$ for oestradiol, respectively). However, in the presence of oestradiol, PAF $(5 \mathrm{ng} / \mathrm{ml})$ significantly elevated PGE release to $44 \cdot 2 \pm 5 \cdot 8$. No stimulation was observed in the presence of progesterone. Stromal cell medium had no effect on PGE release in gland cell cultures. PGE release was always much lower in stromal cell cultures than in glands (control: $4.7 \pm 0.6$ ). PAF stimulated PGE release in the presence of oestradiol in these cells also; gland cell medium was without effect. In co-cultures of glandular and stromal cells, PGE release was more similar to that seen in gland cell cultures, with PAF being stimulatory under the influence of oestradiol. PGF release into the medium from the same gland cell cultures was significantly elevated by hormonal treatment, being greatest $(62 \cdot 0 \pm 11 \cdot 3)$ with oestradiol alone, and was strongly inhibited in all wells by addition of PAF and stromal cell medium. In stromal cell cultures without hormonal addition, PGF levels $(15 \cdot 0 \pm 2 \cdot 4)$ were similar to those seen in glands $(18 \cdot 1 \pm 3 \cdot 1)$, and no stimulation was achieved by oestradiol $(29 \cdot 6 \pm 5 \cdot 9)$. PAF was inhibitory on PGF release, while gland cell medium was without effect. Co-cultures gave PGF values generally similar to those of stromal cells; oestradiol was again stimulatory $(55 \cdot 0 \pm 9 \cdot 3)$. PAF was significantly inhibitory in the presence of oestradiol. PAF (mean \pm s.e.m.: pmol/mg protein $/ 24 \mathrm{~h}$ using a platelet serotonin release assay) in stromal cells was significantly increased from control [M199 alone] $(0 \cdot 31 \pm 0 \cdot 12)$ by progesterone $(1 \cdot 00 \pm 0 \cdot 17)$. Addition of PGE-2 $(7 \cdot 5 \mathrm{ng} / \mathrm{ml})$ to progesterone-treated wells further increased PAF concentration (5.34 $\pm 0 \cdot 09)$, but was without effect in wells receiving oestradiol alone. Wells exposed to both hormones exhibited an intermediate response. Similar results were obtained with addition of gland cell culture medium, presumably due to its endogenous PGE content. In co-cultures, PAF concentrations were significantly elevated by progesterone alone $(4.78 \pm 0.78)$ or when combined with oestradiol $(2.38 \pm 0.51)$, but not by oestradiol alone. Treatment with PGE- 2 caused no additional stimulation. In summary, PAF in stromal cells was increased by PGE-2 in the presence of progesterone, while PGE from gland cells was increased and PGF decreased by PAF in the presence of oestradiol. Gland cell medium exerted effects consistent with the presence of endogenous PGE-2. These results suggest a paracrine interaction between PAF and PGs in regulation of endometrial cell function.

Keywords: platelet-activating factor; PAF; prostaglandins; endometrium; human

*Reprint requests to: Michael J. K. Harper. 


\section{Introduction}

Platelet activating factor (PAF), a potent lipid chemical mediator, has been chemically identified as 1-0-alkyl-2-acetyl-sn-glycero-3-phosphorylcholine (Demopoulos et al., 1979). PAF is synthesized in response to various stimuli in a variety of different cells including neutrophils, basophils, monocytes and mast cells and is one of the most potent secondary inflammatory mediators in mammalian tissues (Braquet et al., 1987; Hanahan \& Kumar, 1987; Pinckard et al., 1988; Snyder, 1989). PAF induces platelets to aggregate and to secrete serotonin within $1 \mathrm{~min}$ at $10^{-10}$ to $10^{-11} \mathrm{M}$ (Pinckard et al., 1979). PAF has been shown to initiate a number of biological reactions, such as contraction of smooth muscle and increase in vascular permeability (Findlay et al., 1981; Tokumura et al., 1984), negative ionotropic cardiac effects (Benveniste et al., 1983; Levi et al., 1984), vasoconstriction (Björk \& Smedegård, 1983; Buxton et al., 1986), exocrine gland stimulation (Soling et al., 1984), glycogenolysis in the fed (perfused) liver (Shukla et al., 1983) and is present in amniotic fluid during labour (Billah \& Johnston, 1983; Billah et al., 1985).

PAF is produced by mouse (O'Neill, 1985a, b; Angle et al., 1988a) and human zygotes (O'Neill et al., 1985; Collier et al., 1988), but not by unfertilized ova (O'Neill, 1987; O'Neill et al., 1987), and has been suggested to be an important mediator of maternal recognition of pregnancy (O'Neill, 1987). This suggestion is supported by studies of mice and rabbits in which PAF-induced secretion of early pregnancy factor was demonstrated (Orozco et al., 1986; Sueoka et al., 1988). PAF has been found in rat (Yasuda et al., 1986, 1988) and rabbit (Angle et al., 1988b) uterus. PAF appeared to be located mainly in the endometrium and increased significantly during the first few days of pregnancy and pseudopregnancy in rabbits. In the pregnant animals, uterine PAF levels dropped precipitously between Days 6 and 7 (i.e. just before implantation) especially at the implantation site (Angle et al., 1988b). These results suggested that (1) uterine PAF levels might be hormonally controlled, and that (2) PAF might be released to cause the increased permeability at the implantation site.

In previous work using cultured human luteal endometrial cells (Alecozay et al., 1989b), we confirmed that PAF is found in stromal cells but not in glandular epithelial cells, and that PAF levels in such cells are increased by progesterone in a dose-dependent manner. PAF was not found in the stromal or glandular cell culture medium. The lack of PAF in the media may imply that PAF remained cell-associated as is the case for stimulated endothelial cells (Whatley et al., 1988), or that released PAF was rapidly metabolized.

Schatz et al. (1987) have shown that both stromal and glandular epithelial cells from the human endometrium release prostaglandin F-2 $\alpha$ (PGF-2 $\alpha$ ) into the culture medium approximately to the same extent. However, Alecozay et al. (1989b) found that oestradiol-stimulated $\left(10^{-8} \mathrm{~mol} / \mathrm{l}\right)$ glandular epithelial cells released both PGF and PGE to a greater extent (about a 10-fold increase) than did stromal cells. Smith \& Kelly (1988) reported that PAF dose-dependently stimulated PGE2 release from human uterine glandular epithelial cell cultures, but was without effect or slightly inhibitory on PGF-2 $\alpha$ release. Together, these studies suggest that PGs and PAF are regulated by a paracrine mechanism.

The objective of the present study was to assess the action on human endometrial cell cultures of exogenous and endogenous (stromal) PAF on the glandular cell secretion of PGE and PGF, and the effect of exogenous and endogenous PGE-2 on the stromal cell PAF concentration. Thus, we hoped to establish the presence of a paracrine relationship between PAF and PGs in stromal and glandular epithelial cells. A preliminary account of this work has been presented (Alecozay et al., 1989a).

\section{Materials and Methods}

Chemicals. Oestradiol-17ß, progesterone, hydrocortisone, Triton X-100, insulin-transferrin-sodium selenite media supplement and PAF C16:0 were obtained from Sigma Chemical Co. (St Louis, MO, USA); collagenase, Medium 199 
with L-glutamine, heat-inactivated fetal calf serum, penicillin/streptomycin and fungizone were from Gibco Laboratories (Grand Island, NY, USA); epidermal growth factor was from Collaborative Research (Bedford, MA, USA); PGE-2 was from Upjohn Co. (Kalamazoo, MI, USA); thrombin was from Parke-Davis (Grand Prairie, TX, USA); bovine serum albumin (BSA) was from ICN Immunobiologicals (Irvine, CA, USA); $5-\left[1,2-{ }^{3} \mathrm{H}(\mathrm{N})\right]$-hydroxytryptamine creatinine sulphate $\left(\left[{ }^{3} \mathrm{H}\right]\right.$ serotonin, sp. act. $15-30 \mathrm{Ci} / \mathrm{mmol}$ ) was from NEN Research Products (Wilmington, DE, USA); Liquiscint scintillation cocktail was from National Diagnostics (Somerville, NJ, USA).

Tissue procurement. Endometrial specimens were obtained from 27 women (aged 24-41 years) undergoing elective hysterectomy for non-endometrial pathology, i.e. cervical dysplasia or uterine prolapse or at endometrial biopsy during the luteal phase. The day of the ovarian cycle at the time of hysterectomy was assessed by histological criteria (Noyes et al., 1950), and the luteal phase was further verified by measurement of the concentration of progesterone in peripheral plasma on the day of surgery (progesterone concentration $>2 \cdot 0 \mathrm{ng} / \mathrm{ml}$ ).

Tissue processing and culture. A sample of uterine tissue not required for pathological evaluation was immediately brought to the laboratory on ice. Isolated cell preparations were made following the method of Schatz et al. (1987), as described previously (Alecozay et al., 1989b). Briefly, endometrial tissue was dissected under aseptic conditions in a laminar flow hood, enzymically digested with collagenase $(1 \mathrm{mg} / \mathrm{ml})$ at $37^{\circ} \mathrm{C}$ in an atmosphere of $5 \% \mathrm{CO}_{2}: 95 \%$ air for $2 \mathrm{~h}$. Cell separation was assisted by frequent gentle pipetting and effected by filtration through 350 and $35 \mu \mathrm{m}$ nylon meshes. The cells were washed with basal medium which consisted of M199, with $5 \%$ heat-inactivated fetal calf serum, Mito + (im serum extender at 1:1000 dilution, $2 \mathrm{~mm}$-glutamine, $100000 \mathrm{IU}$ penicillin/l, $100 \mathrm{mg}$ streptomycin/l, $0.25 \mathrm{mg}$ fungizone $/ 1,10 \mathrm{mg}$ insulin $/ 1,10 \mathrm{mg}$ transferrin $/ 1,10 \mu \mathrm{g}$ selenite $/ 1,1 \mu \mathrm{M}$-hydrocortisone, and $10 \mu \mathrm{g}$ epidermal growth factor/l. Cells were plated in $2 \mathrm{ml}$ basal medium using Corning 6-well plastic tissue-culture plates (Corning Glass Works, Corning, NY, USA). Stromal cells were plated at $10^{6}$ cells $/ 35-\mathrm{mm}$ well in basal medium. The glands were plated at a density of $400 / \mathrm{cm}^{2}( \pm 20)$ in 35 - $\mathrm{mm}$ wells. Co-cultures were done with equivalent numbers of cells. Cultures were incubated in moist air with $5 \% \mathrm{CO}_{2}$ at $37^{\circ} \mathrm{C}$, and medium changed daily. Experimental treatments were started $24 \mathrm{~h}$ after initial plating of the cells, by which time the cells had reached confluence. The viability and purity of these cell cultures have been previously established (Alecozay et al., 1989b). Cultures derived from 5 subjects did not grow well or became contaminated and were not used for experiments.

For each 6-well plate, one cell sample was used for protein estimation using the Bio-Rad procedure (Bio-Rad Laboratories, Richmond, CA, USA), two served as control without hormones, and the remainder were treated with hormones as described below. All hormone-treated wells were exposed to a constant concentration of oestradiol, $10^{-8} \mathrm{M}$, from 24 to $48 \mathrm{~h}$, and then to oestradiol (same concentration), progesterone $\left(10^{-6} \mathrm{M}\right.$ ) or both hormones combined for a further $24 \mathrm{~h}$ ( $48-72 \mathrm{~h}$ of culture) before collection for various assays. On additional 6-well plates, the hormone-treated wells received, over the final $24 \mathrm{~h}$ of culture, certain other treatments, as follows: PAF ( $5 \mathrm{ng} / \mathrm{ml}$; $10 \mathrm{~nm}$ final concentration), PGE-2 $(7.5 \mathrm{ng} / \mathrm{ml} ; 21 \mathrm{nM}$ final concentration) or $100 \mu \mathrm{l}$ culture medium from a $2 \mathrm{ml}$ total volume obtained from 24-h stromal or gland cell control cultures (without hormones).

PAF measurements were made only on the stromal cells, since in previous experiments PAF had not been found in the medium or in glandular epithelial cells (Alecozay et al., 1989b). PAF content was expressed as pmol/mg protein $/ 24 \mathrm{~h}$.

For the PG measurements by radioimmunoassay, $1-\mathrm{ml}$ samples of medium were taken from the cultures at the same time as cells were harvested for PAF assays. The results were initially calculated as $\mathrm{ng} / \mathrm{ml} / 24 \mathrm{~h}$ to be comparable with previous studies. Recalculation as $\mathrm{ng} / \mathrm{mg}$ protein $/ 24 \mathrm{~h}$ showed that in 4 out of 6 analyses of variance the coefficient of variation was reduced by 1.8 to $7.6 \%$ and only elevated by 2.0 and $3.9 \%$ in the remaining two. Results have therefore been expressed in $\mathrm{ng} / \mathrm{mg}$ protein $/ 24 \mathrm{~h}$.

Radioimmunoassay. The PGs in the tissue culture media were measured by the RIA procedure described by Harper et al. (1981), and modified by Jones et al. (1986). The antibodies were obtained from Advanced Magnetics, Inc. (Cambridge, MA, USA). The inter- and intra-assay coefficients of variation were, respectively, $7.0 \%$ and $8.7 \%$ for PGF and $11.5 \%$ and $8.8 \%$ for PGE. Since the antibodies do not discriminate between the one and two series of PGs, the PGs have been indicated generically as PGE or PGF.

Progesterone in the plasma samples was measured in a routine radioimmunoassay previously described by Pauerstein et al. (1978).

PAF extraction and assays. Cell samples were extracted using the method of Bligh \& Dyer (1959), as described previously (Alecozay et al., 1989b). After centrifugation at $800 \mathrm{~g}$ for $10 \mathrm{~min}$ to pellet any cell debris, the supernatant was decanted, and partitioned into aqueous and organic phases by further addition of chloroform and water. The lower (chloroform-rich) layer, containing the extracted lipids, was collected and evaporated under $\mathrm{N}_{2}$ and redissolved in $150 \mu \mathrm{l} \mathrm{chloroform} / \mathrm{methanol}(1: 1, \mathrm{v} / \mathrm{v})$ for separation on silica gel G plates $(500 \mu \mathrm{m}$ thick layer, $10 \times 20 \mathrm{~cm})$ (Analtech, Newark, DE, USA) pre-washed in a neutral solvent system of chloroform/methanol/water (65:35:6, by vol.), allowed to air dry, and then activated by heating at about $150^{\circ} \mathrm{C}$ for $20 \mathrm{~min}$. A standard consisting of lyso-phosphatidylcholine (lyso-PC), sphingomyelin and PC was applied to the first lane, an extracted sample (from above procedure) to the second, another extracted sample to the third and, finally, the standard to the fourth lane. Plates were then developed in the same neutral solvent system. Silica gel from the sample lanes was scraped from an area corresponding to just above lyso-PC to just below PC, using the standards as references. This PAF-containing fraction also includes any sphingomyelin present, which does not affect PAF-induced aggregation of, or serotonin secretion from, washed rabbit platelets. 
The collected silica gel was subjected to lipid extraction (Bligh \& Dyer, 1959), and allowed to stand for $30 \mathrm{~min}$. Samples were centrifuged at $800 \mathrm{~g}$ for $10 \mathrm{~min}$ to pellet the silica gel and the supernatant collected. Additional chloroform and water were added to effect phase separation. After vortexing, samples were centrifuged at $800 \mathrm{~g}$ for $10 \mathrm{~min}$, and the lower (chloroform-rich) phase bioassayed for PAF by platelet aggregation or secretion assays which have been described previously (Alecozay et al., 1989b).

The amount of PAF (in pmol) was calculated by plotting $\%$ secretion of $\left[{ }^{3} \mathrm{H}\right]$ serotonin versus PAF concentration (known from.PAF assay curve). The PAF standard curve was plotted first and then the samples. If the percentage secretion of the sample was above the standard curve, the pmol amount of PAF could not be calculated, and the samples had to be diluted and re-assayed. Since the original volume of the tested samples was $50 \mu \mathrm{l}$ and that of the PAF was $200 \mu \mathrm{l}$, the maximum amount of PAF standard in a tube is $5.0 \mathrm{pmol}$ and for the samples $1.25 \mathrm{pmol}$.

Statistical analysis. The values of the non-hormonally treated control groups were subjected to an analysis of variance (ANOVA) after use of Cochran's test for non-homogeneity of within-group variances (Dixon \& Massey, 1957), which resulted in exclusion of only 2 values in one control set; no significant differences between means of control groups were observed and all control values for each set of experiments were pooled. Since a three-way ANOVA indicated significant interactions between treatment, hormonal regimen and tissue, values for each PG and for PAF were analysed separately by tissue. Each set of treatment mean values and pooled control mean value were again subjected to Cochran's test. No indication of non-homogeneity of variances was detected in any of the 8 analyses ( 3 for PGE, 3 for PGF and 2 for PAF values). The PG values were then analysed by ANOVA and StudentNewman-Keuls (SNK) procedure with $P<0.05$ (SAS Institute, Cary, NC). Since some PAF values in the control groups were below the sensitivity of the assay, the lower limit of the range of measurements was considered fixed. Thus, the values were rank-ordered before analysis by ANOVA and the SNK procedure.

\section{Results}

\section{PGE release from endometrial cell cultures}

Table 1 shows the concentrations of PGE (mean \pm s.e.m.) measured in the culture medium of endometrial cell cultures. PGE values did not differ significantly with any hormonal treatment. However, in the presence of oestradiol alone, PAF $(5.0 \mathrm{ng} / \mathrm{ml})$ significantly elevated PGE release over the oestradiol control. In wells treated with progesterone, or oestradiol and progesterone, PAF was not stimulatory, and the levels were significantly lower than in the presence of oestradiol alone. Stromal culture medium ( $100 \mu \mathrm{l}$ from $2 \mathrm{ml}$ original volume) when added with $1.9 \mathrm{ml}$ fresh medium to these glandular cell cultures, had no effect on PGE release, either stimulatory or inhibitory, under any hormonal regimen.

In stromal cell cultures (Table 1), PGE levels in control wells were significantly lower than in glandular cell cultures $(P<0.05)$ and were unaffected by hormonal treatment. PAF significantly stimulated PGE release in both the oestradiol- and progesterone-treated wells compared to the comparable wells receiving only the same hormone, but not in those treated with both hormones. Although absolute values were lower than those achieved in glandular cell cultures, the degree of stimulation ( $\sim 2$-fold) over the respective hormonally-treated control wells was similar for oestradiol-treated glandular and stromal cell cultures. Addition of glandular cell culture medium ( $100 \mu \mathrm{l}$ from $2 \mathrm{ml}$ original volume) was without effect under any hormonal treatment.

When co-cultures of separated glandular and stromal cells were done (Table 1), results for PGE intermediate between those from gland and stromal cell cultures alone were observed in the control wells. PGE release was significantly elevated by both oestradiol alone and progesterone plus oestradiol, to levels similar to those seen in gland cells. PAF again was strongly stimulatory in the presence of oestradiol alone or when combined with progesterone, but not in the presence of progesterone alone. In these co-cultures, PAF only increased PGE release about $1 \cdot 5$-fold in the most favourable circumstance.

\section{PGF release from endometrial cell cultures}

PGF values in the media from the same three sets of cultures sampled for PGE are shown in Table 2. In gland cell cultures, PGF release in control wells was similar to that seen for PGE. PGF release was significantly stimulated by all hormonal treatments, being greatest with oestradiol 
Table 1. Concentration of PGE (ng/mg protein $/ 24 \mathrm{~h}$ : mean \pm s.e.m., no. of wells* in parentheses) in the medium from cultured endometrial cells

\begin{tabular}{|c|c|c|c|c|c|}
\hline \multirow[b]{2}{*}{ Cell type } & \multirow[b]{2}{*}{$\begin{array}{l}\text { Additional } \\
\text { treatment } \dagger\end{array}$} & \multicolumn{4}{|c|}{ Hormonal treatment } \\
\hline & & None & $\begin{array}{l}\text { Progesterone } \\
\quad\left(10^{-6} \mathrm{M}\right)\end{array}$ & $\begin{array}{c}\text { Oestradiol } \\
\left(10^{-8} \mathrm{M}\right) \text { plus } \\
\text { progesterone } \\
\left(10^{-6} \mathrm{M}\right)\end{array}$ & $\begin{array}{l}\text { Oestradiol } \\
\left(10^{-8} \mathrm{M}\right)\end{array}$ \\
\hline \multirow[t]{3}{*}{$\begin{array}{l}\text { Glandular epithelial } \\
\text { cells }\end{array}$} & None & ${ }_{(17)}^{17 \cdot 6 \pm 1 \cdot 3+c, d}$ & $11 \cdot 4 \pm \frac{ \pm}{(7)} 1 \cdot 7^{d}$ & $20 \cdot 0 \underset{(7)}{ \pm} 1 \cdot 5^{b, c, d}$ & 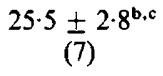 \\
\hline & $\begin{array}{l}\text { Stromal cell } \\
\text { culture medium }\end{array}$ & - & $18 \cdot 1 \underset{(5)}{ \pm} 2 \cdot 8^{b, c, d}$ & $16 \cdot 3 \underset{(5)}{ \pm} 1 \cdot 4^{\mathrm{c}, \mathrm{d}}$ & $24 \cdot 6 \frac{ \pm}{(5)} 5 \cdot 5^{b, c}$ \\
\hline & PAF & - & $20 \cdot 8 \underset{(5)}{ \pm} 1 \cdot 2^{b, c, d}$ & $29 \cdot 7 \underset{(5)}{ \pm} 2 \cdot 0^{\mathrm{b}}$ & $44 \cdot 2 \pm 5 \cdot 8^{a}$ \\
\hline \multirow[t]{3}{*}{ Stromal cells } & None & $\begin{array}{l}4 \cdot 7 \pm 0 \cdot 6_{+}^{+p} \\
(17)\end{array}$ & $4 \cdot 2 \frac{ \pm}{(7)} 0 \cdot 4^{p}$ & $7 \cdot 7 \pm 0 \cdot 6^{0, p}$ & $8 \cdot 8 \frac{ \pm}{(7)} 0 \cdot 8^{o, p}$ \\
\hline & $\begin{array}{l}\text { Gland cell } \\
\text { culture medium }\end{array}$ & - & $4 \cdot 2 \pm 0.4^{p}$ & $8 \cdot 2 \pm 0.9^{o, p}$ & $10 \cdot 5 \pm 2 \cdot 0^{\circ}$ \\
\hline & PAF & - & $14 \cdot 8 \underset{(5)}{ \pm} 3 \cdot 0^{n}$ & $7 \cdot 5 \underset{(5)}{ \pm} 2 \cdot 1^{0 . p}$ & $18 \cdot 9 \pm \frac{ \pm}{(5)} 1 \cdot 8^{m}$ \\
\hline \multirow[t]{2}{*}{$\begin{array}{l}\text { Co-cultures of glandular } \\
\text { and stromal cells }\end{array}$} & None & $\begin{array}{l}9 \cdot 6 \pm 2 \cdot 1 \ddagger^{2} \\
(12)\end{array}$ & $8 \cdot 1 \pm 1 \cdot 8^{2}$ & $23 \cdot 1 \underset{(7)}{ \pm} 1 \cdot 4^{y}$ & $26 \cdot 9 \frac{ \pm}{(7)} 3 \cdot 2^{x, y}$ \\
\hline & PAF & - & $14 \cdot 4 \underset{(5)}{ \pm} 1 \cdot 1^{2}$ & $32 \cdot 9 \pm \frac{2 \cdot 2^{w, x}}{(5)}$ & $38 \cdot 9 \pm \frac{ \pm}{(5)} 4 \cdot 0^{\mathrm{w}}$ \\
\hline
\end{tabular}

*Each well represented tissue from a different subject.

†Additional treatments for $24 \mathrm{~h}$ of experiment were: nothing, $100 \mu \mathrm{l}$ from a 2-ml volume of a stromal or a glandular epithelial cell culture not exposed to hormones, or $5 \mathrm{ng} \mathrm{PAF} / \mathrm{ml}$ (final concentration).

$\ddagger$ Control group means did not differ between experiments and have been pooled. Letter superscripts indicate significant differences determined by ANOVA and Student-Newman-Keuls test $(P<0.05)$ : $a$ is different from $b$, but $b$ is not different from $b, c$, etc.: $m$ is different from $n$ and $o$, but $o$ is not different from $o, p$, etc.: $w$ is not different from $\mathrm{w}, \mathrm{x}$ and $\mathrm{w}, \mathrm{x}$ is not different from $\mathrm{x}, \mathrm{y}$ etc.

alone. Compared to the respective hormonally-treated control wells, treatment with stromal cell medium or PAF was significantly inhibitory and gave values similar to the control group in the absence of hormones.

In stromal cell cultures (Table 2), the control level of PGF was not different from that seen in glands, and no stimulation was achieved by oestradiol. No stimulation was seen in the presence of progesterone. In these cultures, gland cell medium was without effect. PAF was strongly inhibitory in the presence of progesterone or oestradiol, and showed the same trend in wells receiving both hormones, compared to respective hormone-treated wells.

The co-cultures under hormonal influence produced PGF levels generally similar to those seen in stromal cell cultures. The control value in the absence of hormones was similar to those observed in glands and stroma alone. A significant elevation of PGF release was seen only in the presence of oestradiol alone. PAF was inhibitory only in the presence of oestradiol alone.

\section{PAF concentration in stromal cell cultures}

Since in similar experiments previously reported (Alecozay et al., 1989b), PAF had not been detected in gland cell cultures or in medium from gland or stromal cell cultures, such samples were not assayed in the present experiments. PAF concentrations in stromal cells (mean \pm s.e.m. in $\mathrm{pmol} / \mathrm{mg}$ protein $/ 24 \mathrm{~h}$ ) are shown in Table 3 . PAF concentration was higher in progesteronetreated cultures than in controls, which was similar to previous experiments (Alecozay et al., 
Table 2. Concentration of PGF (ng/mg protein/24 h: mean \pm s.e.m., no. of wells* in parentheses) in the medium from cultured endometrial cells

\begin{tabular}{|c|c|c|c|c|c|}
\hline \multirow[b]{2}{*}{ Cell type } & \multirow[b]{2}{*}{$\begin{array}{l}\text { Additional } \\
\text { treatment }{ }^{\dagger}\end{array}$} & \multicolumn{4}{|c|}{ Hormonal treatment } \\
\hline & & None & $\begin{array}{l}\text { Progesterone } \\
\quad\left(10^{-6} \mathrm{M}\right)\end{array}$ & $\begin{array}{c}\text { Oestradiol } \\
\left(10^{-8} \mathrm{M}\right) \text { plus } \\
\text { progesterone } \\
\left(10^{-6} \mathrm{M}\right)\end{array}$ & $\begin{array}{l}\text { Oestradiol } \\
\left(10^{-8} \mathrm{M}\right)\end{array}$ \\
\hline \multirow[t]{3}{*}{$\begin{array}{l}\text { Glandular epithelial } \\
\text { cells }\end{array}$} & None & $\begin{array}{l}18 \cdot 1 \pm 3 \cdot 1 t^{b} \\
(15)\end{array}$ & $46 \cdot 8 \pm 7 \cdot 1^{a}$ & $44 \cdot 3 \pm 6 \cdot 3^{a}$ & $62 \cdot 0 \pm 11 \cdot 3^{a}$ \\
\hline & $\begin{array}{l}\text { Stromal cell } \\
\text { culture medium }\end{array}$ & - & $8 \cdot 8 \pm 3 \cdot 3^{b}$ & $18 \cdot 7 \pm 1 \cdot 3^{b}$ & $18 \cdot 6 \pm \frac{ \pm}{(5)} 4 \cdot 3^{b}$ \\
\hline & PAF & - & $13 \cdot 1 \pm 3 \cdot 0^{b}$ & $14 \cdot 0 \pm \frac{2}{(5)} 1^{b}$ & $16 \cdot 6 \pm \frac{ \pm}{(5)} 1 \cdot 4^{b}$ \\
\hline \multirow[t]{3}{*}{ Stromal cells } & None & $\begin{array}{l}15 \cdot 0 \pm 2 \cdot 4_{+}^{\mathrm{n}, 0, p} \\
(17)\end{array}$ & $23 \cdot 4 \pm \frac{ \pm \cdot 3^{n, o}}{(7)}$ & $16 \cdot 0 \pm 2 \cdot 9^{n, o, p}$ & $29 \cdot 6 \underset{(7)}{ \pm} 5 \cdot 9^{n}$ \\
\hline & $\begin{array}{l}\text { Gland cell } \\
\text { culture medium }\end{array}$ & - & $8 \cdot 5 \pm \frac{ \pm}{(5)} 1 \cdot 8^{o, p}$ & $17 \cdot 8 \pm 3 \cdot 3 \cdot 9^{n, o, p}$ & $43 \cdot 8 \underset{(5)}{ \pm} 2 \cdot 8^{m}$ \\
\hline & PAF & - & $6 \cdot 7 \pm 1 \cdot 3^{p}$ & $7 \cdot 5 \pm 0.4^{0, p}$ & $9 \cdot 3 \pm \frac{ \pm}{(5)} 0 \cdot 9^{0, p}$ \\
\hline \multirow[t]{2}{*}{$\begin{array}{l}\text { Co-cultures of glandular } \\
\text { and stromal cells }\end{array}$} & None & $\begin{array}{l}15 \cdot 8 \pm 2 \cdot 3 t^{+x} \\
(12)\end{array}$ & $16 \cdot 0 \pm 3 \cdot 4^{x}$ & $27 \cdot 9 \pm 5 \cdot 0^{x}$ & $55 \cdot 0 \underset{(7)}{ \pm} 9 \cdot 3^{w}$ \\
\hline & PAF & - & $7 \cdot 4 \pm 1 \cdot 1^{x}$ & $13 \cdot 6 \pm 3 \cdot 3^{x}$ & $18 \cdot 8 \pm \frac{ \pm}{(5)} 3 \cdot 9^{x}$ \\
\hline
\end{tabular}

*Each well represented tissue from a different subject.

†Additional treatments for $24 \mathrm{~h}$ of experiment were: nothing, $100 \mu \mathrm{l}$ from a 2 -ml volume of a stromal or a glandular epithelial cell culture not exposed to hormones, or $5 \mathrm{ng} \mathrm{PAF} / \mathrm{ml}$ (final concentration).

†Control group means did not differ between experiments and have been pooled. Letter superscripts indicate significant differences determined by ANOVA and Student-Newman-Keuls test $(P<0.05)$ : except a is different from b: $\mathrm{m}$ is different from $\mathrm{n}$, but $\mathrm{n}$ is not different from $\mathrm{n}, \mathrm{o}$ etc.: $\mathrm{w}$ is different from $\mathrm{x}$.

1989b). Addition of PGE-2 $(7.5 \mathrm{ng} / \mathrm{ml})$ to the cultures containing progesterone significantly elevated PAF concentrations. These were maximal with progesterone alone, showing a 5-fold increase over the progesterone-treated control group. Gland cell medium (presumably because of its content of PGE) also significantly elevated PAF levels over those in the progesterone-treated control wells. Although the PAF concentration in the presence of both progesterone and oestradiol was not significantly different from the non-hormone treated control, it was intermediate between the control and progesterone alone values. Addition of gland cell medium and PGE-2 in the presence of both progesterone and oestradiol significantly elevated PAF over the hormonally-treated control value. No such effect was seen in the presence of oestradiol alone.

In the co-cultures of endometrial glandular and stromal cells (Table 3), PAF concentrations were significantly elevated (14-fold) by progesterone alone or (7-fold) by progesterone plus oestradiol, but not by oestradiol alone. PGE-2 treatment did not change these concentrations, compared respectively to the wells receiving the same steroid alone. These complex interactions have been diagrammatically summarized in Fig. 1.

\section{Discussion}

In the present experiments, both PGE and PGF were released by glandular epithelial and stromal cell cultures. PGE release was unchanged by hormonal treatment in either type of cell culture, while that of PGF was elevated significantly in glandular cell cultures. In general, PG concentrations 
Table 3. Concentration of PAF (pmol/mg protein $/ 24 \mathrm{~h}$ : mean \pm s.e.m., no. of wells* in parentheses) in cultured endometrial cells

\begin{tabular}{|c|c|c|c|c|c|}
\hline \multirow[b]{2}{*}{ Cell type } & \multirow[b]{2}{*}{$\begin{array}{l}\text { Additional } \\
\text { treatment } \dagger\end{array}$} & \multicolumn{4}{|c|}{ Hormonal treatment } \\
\hline & & None & $\begin{array}{l}\text { Progesterone } \\
\quad\left(10^{-6} \mathrm{M}\right)\end{array}$ & $\begin{array}{c}\text { Oestradiol } \\
\left(10^{-8} \mathrm{M}\right) \text { plus } \\
\text { progesterone } \\
\left(10^{-6} \mathrm{M}\right)\end{array}$ & $\begin{array}{l}\text { Oestradiol } \\
\left(10^{-8} \mathrm{M}\right)\end{array}$ \\
\hline \multirow[t]{3}{*}{ Stromal cells } & None & $0.31 \pm 0.12 t^{\mathfrak{c}}$ & $1 \cdot 00 \pm \frac{0.17^{b}}{(5)}$ & $0 \cdot 68 \underset{(5)}{ \pm 0} 0 \cdot 22^{\mathrm{b}, \mathrm{c}}$ & $0 \cdot 15 \pm \frac{ \pm 04^{c}}{(5)}$ \\
\hline & $\begin{array}{l}\text { Gland cell } \\
\text { culture medium }\end{array}$ & - & $3.64+0.86^{\mathrm{a}}$ & $2 \cdot 19 \underset{(5)}{ \pm} 0 \cdot 45^{\mathrm{a}}$ & $0.91 \underset{(5)}{ \pm} 0 \cdot 34^{b . c}$ \\
\hline & $\mathrm{PGE}_{2}$ & - & $5 \cdot 34 \underset{(5)}{ \pm 0.09^{a}}$ & $3.06 \pm \frac{ \pm}{(5)} 0.25^{a}$ & $0 \cdot 74 \underset{(5)}{ \pm 0} 0 \cdot 18^{b \cdot c}$ \\
\hline \multirow[t]{2}{*}{$\begin{array}{l}\text { Co-cultures of glandular } \\
\text { and stromal cells }\end{array}$} & None & $\begin{array}{c}0.35 \pm 0.12 \ddagger^{2} \\
(10)\end{array}$ & $4.78 \underset{(5)}{ \pm 0.78^{x}}$ & $2 \cdot 38 \underset{(5)}{ \pm} 0.51^{y}$ & $1 \cdot 13 \pm \frac{ \pm}{(5)} 0 \cdot 28^{z}$ \\
\hline & $\mathrm{PGE}_{2}$ & - & $4 \cdot 42 \pm 0.47^{x}$ & $2.92 \underset{(5)}{ \pm} 0.23^{x, y}$ & $0 \cdot 82 \frac{ \pm}{(5)} 0 \cdot 15^{z}$ \\
\hline
\end{tabular}

*Each well represented tissue from a different subject.

†Additional treatments for $24 \mathrm{~h}$ of experiment were: nothing, $100 \mu \mathrm{l}$ sample from a 2 -ml volume of a gland cell culture not exposed to hormones, or $7.5 \mathrm{ng}$ PGE-2/ml (final concentration).

$\ddagger$ Control groups did not differ between experiments and have been pooled. Letter superscripts indicate significant differences determined by ANOVA and Student-Newman-Keuls test $(P<0.05)$ : $\mathrm{a}$ is different from $\mathrm{b}$, but $\mathrm{b}$ is not different from $b, c$, etc.: $x$ is different from $y$, but not from $x, y$ etc.

were higher in gland cell than in stromal cell cultures. These trends are in agreement with those reported by Schatz et al. (1987), Smith \& Kelly (1988) and Alecozay et al. (1989a). The values reported appear similar to those reported by Schatz et al. (1987) and ourselves previously (Alecozay et al., 1989b), but considerably lower than those of Smith \& Kelly (1988), who conducted their experiments over a much shorter period of culture $(24 \mathrm{~h}$ total) than the other studies. In the co-cultures of glands and stroma, however, a modest stimulation of both PGE and PGF release by oestradiol was observed, the levels being similar to those seen in the glands alone. Stromal cell culture medium added to gland cell cultures did not alter PGE release, but inhibited PGF release. Gland cell culture medium added to stromal cell cultures did not alter PGE or PGF levels under any hormonal condition. These results imply that there is a differential control of PGE and PGF release from endometrial cells, especially under the influence of oestradiol.

Smith \& Kelly (1988) reported that 10 or 100 , but not 1 , ng PAF/ml added to non-hormonally stimulated gland cell cultures increased PGE- 2 release into the medium and left PGF- $2 \alpha$ unaltered or slightly inhibited. In their stromal cell cultures, PAF had no effect on either PG. In the present experiments, PAF $(5 \mathrm{ng} / \mathrm{ml}: 10 \mathrm{nM})$ in the presence of oestradiol significantly stimulated PGE release, and inhibited PGF release, from glandular and stromal cell cultures and co-cultures. The modest increases of PGE observed in cultures receiving only progesterone were not, in general, significant while those observed in the presence of oestradiol and progesterone were intermediate, with that in the co-culture being significant. These results confirm and extend the original observations of Smith \& Kelly (1988).

Nakashima et al. (1989) found that as little as $8 \mathrm{~nm}-\mathrm{PAF}$ (very similar to the concentration used in the present experiments) significantly stimulated release of $\left[{ }^{3} \mathrm{H}\right]$ arachidonic acid from human neutrophils and that maximal stimulation was achieved with $800 \mathrm{nM}$ within $5 \mathrm{~min}$. Intracellular calcium mobilization in the same cells was stimulated by PAF at concentrations as low as $80 \mathrm{pM}$. These authors concluded that PAF activated a calcium-dependent phospholipase A-2 through a Pertussis-sensitive $G$ protein. Arachidonic acid released by such a mechanism could provide the substrate for the increased PGE formation in response to PAF in the present experiments, but does 


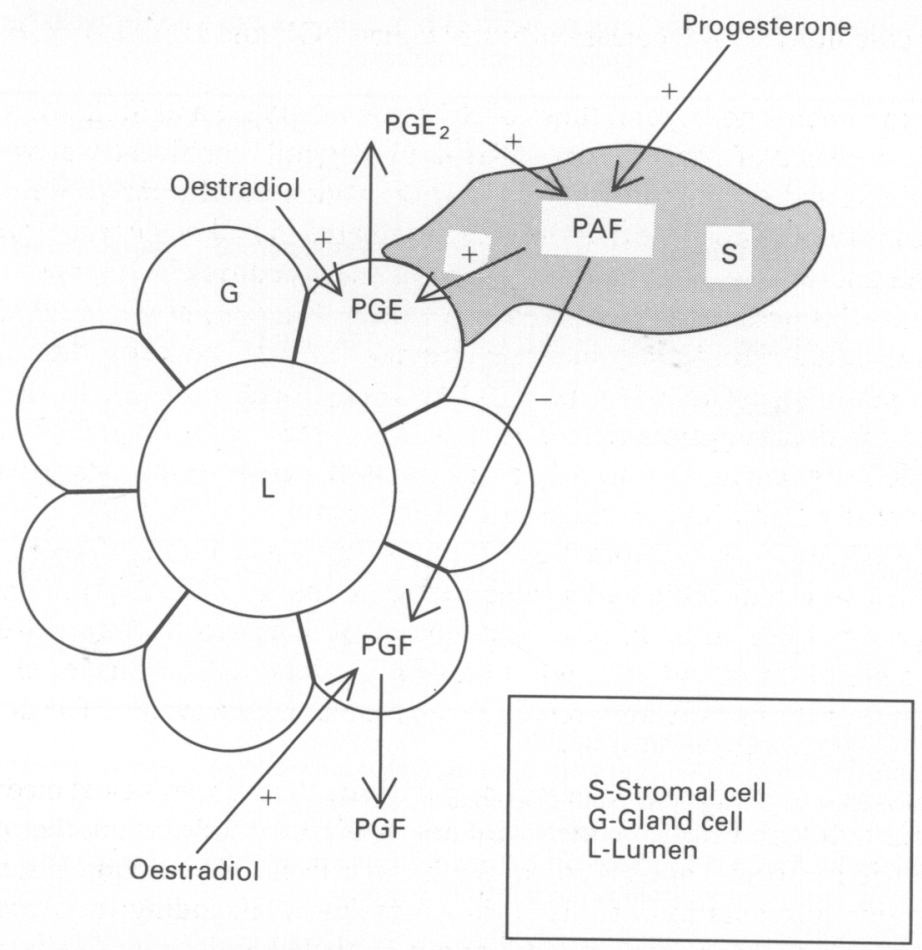

Fig. 1. A diagrammatic representation of the interactions (+, stimulatory; - , inhibitory) between mediators released from endometrial glandular epithelial and stromal cells. PGE and PGF represent prostaglandins $E$ and $F$ measured by radioimmunoassay. PGE-2 is used to indicate use of the chemically identified prostaglandin. The hormone names indicate addition of a particular steroid to the culture for the $24 \mathrm{~h}$ before sampling at the same doses indicated elsewhere.

not explain the divergent responses of PGE and PGF which usually increase or decrease in tandem. Smith \& Kelly (1987) provided one possible explanation for this discrepancy, when they found that addition of excess arachidonic acid to human endometrial cells caused a disproportionate increase in PGE-2 synthesis compared to that of PGF-2 $\alpha$. A second possibility is that differential metabolism by 15-hydroxyprostaglandin dehydrogenase (EC 1.1.1.141) might occur; the resulting 15 -keto metabolites would cross-react very weakly in the radioimmunoassay. However, PGE-2 is more rapidly metabolized by the rabbit uterus, approximately 5-fold faster after $48 \mathrm{~h}$ exposure to progesterone, than PGF-2 $\alpha$ (Bodkhe \& Harper, 1979), and consequently PGF-2 $\alpha$ should be elevated compared to PGE-2, given equivalent amounts of synthesis. A similarly increased specificity of this enzyme for PGE-2 compared to PGF- $2 \alpha$ was exhibited in human decidual tissue obtained at term (Casey et al., 1989). Thirdly, reduced conversion of PGE-2 to PGF-2 $\alpha$ by 9-ketoreductase (EC 1.1.1.189) might occur. This enzyme has been found in rabbit endometrium (Schlegel et al., 1988), and in human endometrial stromal cell cultures (Niesert et al., 1986). The activity of this enzyme in the rabbit uterus is not different between Days 8 and 15 of pregnancy or pseudopregnancy (Schlegel et al., 1988). In the human stromal cell cultures, addition of $10 \mathrm{ng} / \mathrm{ml}$, but not $1 \mathrm{ng} / \mathrm{ml}$, of PGE-2 caused an increase in the amount of PGF-2 $\alpha$ produced, which was due to conversion from the added PGE-2 (Niesert et al., 1986). Conceivably, PAF could increase PGE levels by reduction of the activity of this enzyme. Whatever the mechanism, it is clear from the work of Smith \& Kelly (1988) and ourselves that PAF dramatically increases PGE and depresses PGF content in the medium of cultured glandular epithelial cells. In non-hormonally treated stromal cell cultures, Smith \& Kelly (1988) found no effect of added PAF, while in our oestradiol-treated 
stromal cells and co-cultures, PAF consistently stimulated PGE and inhibited PGF release into the medium.

The present experiments go beyond those of Schatz et al. (1987) and Smith \& Kelly (1988) and show that, in the presence of progesterone, PGE-2 $(7.5 \mathrm{ng} / \mathrm{ml})$ significantly elevates the concentration of PAF in stromal cell cultures. Given that the endometrial samples were obtained from secretory phase samples, it is possible that the PAF originated in leukocytes rather than the stromal cells. However, the increase in PAF concentrations of these cultures in response to progesterone may militate against this possibility. Previous experiments (Alecozay et al., 1989b) had shown that progesterone alone could significantly increase stromal cell PAF concentration (mean \pm s.e.m.) from $0.14 \pm 0.05 \mathrm{pmol} / \mathrm{mg}$ protein $/ 24 \mathrm{~h}(n=14)$ to $1.00 \pm 0.13(n=14)$. In the present experiments, the values for similar groups were $0.35 \pm 0.12(n=15)$ and $1.00 \pm 0.17(n=5) \mathrm{pmol} / \mathrm{mg}$ protein $/ 24 \mathrm{~h}$ respectively, again significantly different. In the co-cultures, progesterone alone also produced a statistically significant increase in PAF concentration. PGE-2 further amplified this progesterone-induced response in stromal cell cultures, but was without effect in the presence of oestradiol alone. Gland cell medium had a similar effect to that of PGE-2, presumably owing to its content of endogenous PGE, although this amount, when added to the new culture, would have been less than $0.5 \mathrm{ng} / \mathrm{ml}$. In co-cultures, addition of PGE-2 caused no further elevation of PAF, since the PAF concentrations were apparently already maximally elevated. The action of PGF- $2 \alpha$ in such experiments has not yet been tested.

The results obtained in the present study clearly indicate that physiological mediators produced by one endometrial cell type can stimulate or inhibit mediators made by another cell. In the midsecretory endometrium, stromal and glandular epithelial cells lie in close apposition (Wynn, 1989), and a diagrammatic representation of this is shown in Fig. 1, including the various interactions found in the present study. PGs are secreted by both epithelial and stromal cells, and it is known that in other species, depending on the sexual stage, i.e. pregnant versus non-pregnant, PG transport can be towards the uterine lumen or the uterine vasculature (Bazer et al., 1986). Transport across the uterine wall from the lumen is also influenced by the same factors (Cao et al., 1984). There is therefore an established transport mechanism for PGs to the stromal cells and PGs can be concentrated in endometrial tissue underlying the implanting blastocyst (Jones et al., 1990).

In contrast, PAF in many situations remains cell-associated, e.g. in endothelial cells (Whatley et al., 1988), and requires the presence of extracellular albumin for secretion (Ludwig et al., 1985). Whether PAF was secreted from endometrial cells in vitro was not determined in the previous (Alecozay et al., 1989b) or present experiments. Although PAF was not found in the culture medium, rapid metabolism by the specific enzyme PAF acetylhydrolase (EC 3.1.1.47), which is found both intracellularly and in plasma (Blank et al., 1983) to lyso-PAF, the major metabolite of PAF, cannot be excluded. Indeed, in cultures in the absence of separated endometrial cells in medium containing heat-inactivated $\left(56^{\circ} \mathrm{C}\right.$ for $\left.30 \mathrm{~min}\right)$ fetal calf serum, rapid metabolism of PAF was observed (M. Kasamo \& M. J. K. Harper, unpublished data). The acetylhydrolase in plasma can, however, be inactivated by heating at $65^{\circ} \mathrm{C}$ for $30 \mathrm{~min}$ (Farr et al., 1983). Specific binding sites for PAF have been identified in the rabbit endometrium (Kudolo \& Harper, 1989b), and appear to be localized to the epithelial cell membranes (Kudolo \& Harper, 1989a), and so direct transmembrane transfer from stromal cell to epithelial cell might be envisaged. Evidence that there is communication between these cell types in vivo is provided by the in-vitro co-culture experiments in which the PAF concentration was elevated, in the absence of exogenous PGE-2, to a concentration produced only by addition of PGE-2 to stromal cell cultures. Furthermore, the facts that (1) PGE secretion could be further stimulated and (2) PGF secretion inhibited, in the oestradiol-treated co-cultures by addition of exogenous PAF, argue against secretion of PAF from stromal cells into the medium in such cultures and for the necessity of normal tissue organization for PAF to control glandular cell PG secretion.

PAF is a potent pro-inflammatory substance which is thought to be involved in the implantation process, perhaps cooperating with PGE-2 to induce the increased vascular permeability 
underlying the implantation site (Harper, 1989). The present experiments were done using uterine tissue from women in the secretory phase of the menstrual cycle, at a time when uterine preparation for implantation would be occurring. The results obtained cannot necessarily be applied to endometrial cells from other stages of the cycle, but should be relevant to the implantation process.

We thank Dr Frank D. DeLeon, Texas Tech University Health Science Center, for provision of some endometrial specimens; Monica Silva Brandt and Terri A. Nouchi for technical assistance; and Beverly Evans for typing the manuscript.

This work was supported by a technical services agreement from the Special Programme of Research, Development and Research Training in Human Reproduction, World Health Organization (WHO 87007) and NIH grants HD14048 and HD10202 (Radioimmunoassay Core).

\section{References}

Alecozay, A.A., Schenken, R.S., Hanahan, D.J., Nouchi, T., Silva, M. \& Harper, M.J.K. (1989a) Paracrine interactions between platelet-activating factor (PAF) and prostaglandin $\mathrm{E}_{2}\left(\mathrm{PGE}_{2}\right)$ in human luteal phase endometrial cell cultures. The Endocrine Society, 71st Ann. Mtg Program Suppl., p. 300, Abstr. 1109.

Alecozay, A.A., Casslén, B.G., Riehl, R.M., DeLeon, F.D., Harper, M.J.K., Silva, M., Nouchi, T.A. \& Hanahan, D.J. (1989b) Platelet-activating factor (PAF) in human luteal phase endometrium. Biol. Reprod. 41, 578-586.

Angle, M.J., Byrd, W. \& Johnston, J.M. (1988a) Embryonic production of platelet-activating factor in culture. Fert. Steril. 44th Ann. Mtg Program Suppl., S96, Abstr. P-158.

Angle, M.J., Jones, M.A., McManus, L.M., Pinckard, R.N. \& Harper, M.J.K. (1988b) Platelet-activating factor in the rabbit uterus during early pregnancy. J. Reprod. Fert. 83, 711-722.

Bazer, F.W., Vallet, J.L., Roberts, R.M., Sharp, D.C. \& Thatcher, W.W. (1986) Role of conceptus secretory products in establishment of pregnancy. J. Reprod. Fert. 76, 84I-850.

Benveniste, J., Boullet, C., Brink, C. \& Labat, C. (1983) The actions of Paf-acether (platelet-activating factor) on guinea-pig isolated heart preparations. Br. J. Pharmacol. 80, 81-83.

Billah, M.M. \& Johnston, J.M. (1983) Identification of phospholipid platelet-activating factor (1-O-alkyl-2acetyl- $S N$-glycero-3-phosphocholine) in human amniotic fluid and urine. Biochem. Biophys Res. Commun. $113,51-58$.

Billah, M.M., Di Renzo, G.C., Ban, C., Truong, C.T., Hoffman, D.R., Anceschi, M.M., Bleasdale, J.E. \& Johnston, J.M. (1985) Platelet-activating factor metabolism in human amnion and the responses of this tissue to extracellular platelet-activating factor. Prostaglandins 30, 841-850.

Björk, J. \& Smedegård, G. (1983) Acute microvascular effects of PAF-acether, as studied by intravital microscopy. Eur. J. Pharmacol. 96, 87-94.

Blank, M.L., Hall, M.N., Cress, E.A. \& Snyder, F. (1983) Inactivation of 1-alkyl-2-acetyl-sn-glycero-3phosphocholine by a plasma acetylhydrolase: higher activities in hypotensive rats. Biochem. Biophys. Res. Commun. 113, 666-671.

Bligh, E.G. \& Dyer, W.J. (1959) A rapid method of total lipid extraction and purification. Can. J. Biochem. Physiol. 37, 911-917.

Bodkhe, R.R. \& Harper, M.J.K. (1979) Influence of hCG injection and steroid treatment on prostaglandin metabolism by rabbit uterus and oviduct. $J$. Reprod. Fert. 57, 101-112.

Braquet, P., Touqui, L., Shen, T.Y. \& Vargaftig, B.B. (1987) Perspectives in platelet-activating factor research. Pharmacol. Rev. 39, 97-145.

Buxton, D.B., Fisher, R.A., Hanahan, D.J. \& Olson, M.S. (1986) Platelet-activating factor-mediated vasoconstriction and glycogenolysis in the perfused rat liver. J. biol. Chem. 261, 644649.

Cao, Z.-d., Jones, M.A. \& Harper, M.J.K. (1984) Prostaglandin translocation from the lumen of the rabbit uterus in vitro in relation to day of pregnancy or pseudopregnancy. Biol. Reprod. 31, 505-519.

Casey, M.L., Delgadillo, M., Cox, K.A., Niesert, S. \& MacDonald, P.C. (1989) Inactivation of prostaglandins in human decidua vera (parietalis) tissue: Substrate specificity of prostaglandin dehydrogenase. Am. J. Obstet. Gynecol. 160, 3-7.

Collier, M., O'Neill, C., Ammit, A.J. \& Saunders, D.M. (1988) Biochemical and pharmacological characterization of human embryo-derived platelet-activating factor. Human Reprod. 3, 993 998.

Demopoulos, C.A., Pinckard, R.N. \& Hanahan, D.J. (1979) Platelet-activating factor. Evidence for 1-Oalkyl-2-acetyl-sn-glyceryl-3-phosphorylcholine as the active component (a new class of lipid chemical mediators). J. biol. Chem. 254, 9355-9358.

Dixon, W.J. \& Massey, F.J., Jr (1957) Introduction to Statistical Analysis, 2nd edn, p. 180. McGraw-Hill, New York.

Farr, R.S., Wardlow, M.L., Cox, C.P., Meng, K.E. \& Greene, D.E. (1983) Human serum acid-labile factor is an acylhydrolase that inactivates platelet-activating factor. Fedn Proc. Fedn Am. Socs exp. Biol. 42, 31203122.

Findlay, S.R., Lichtenstein, L.M., Hanahan, D.J. \& Pinckard, R.N. (1981) Contraction of guinea pig ileal smooth muscle by acetyl glyceryl ether phosphorylcholine. Am. J. Physiol. 241, C130-C133.

Hanahan, D.J. \& Kumar, R. (1987) Platelet activating factor; chemical and biochemical characteristics. Prog. Lipid Res. 26, 1-28.

Harper, M.J.K. (1989) Platelet-activating factor: a 
paracrine factor in preimplantation stages of reproduction? Biol. Reprod. 40,907-913.

Harper, M.J.K., Norris, C.J., Friedrichs, W.E. \& Moreno, A. (1981) Poly I:C accelerates ovum transport in the rabbit by a prostaglandin-mediated mechanism. $J$. Reprod. Fert. 63, 81-89.

Jones, M. A., Cao, Z.-d., Anderson, W., Norris, C. \& Harper, M.J.K. (1986) Capillary permeability changes in the uteri of recipient rabbits after transfer of blastocysts from indomethacin-treated donors. $J$. Reprod. Fert. 78, 261-273.

Jones, M. A., Cao, Z.-d., Norris, C. J., Anderson, W., Hemmick, E. \& Harper, M.J.K. (1990) $\left[{ }^{3}\right.$ H] Prostaglandin uptake in vivo by rabbit uterus and blastocysts. Prostaglandins Leuk. Essent. Fatty Acids 39, 267-275.

Kudolo, G.B. \& Harper, M.J.K. (1989a) Plateletactivating factor binding sites in rabbit endometrium. Biol. Reprod. 40 (Suppl 1), p. 78, Abstr. 92.

Kudolo, G.B. \& Harper, M.J.K. (1989b) Characterization of platelet-activating factor binding sites on uterine membranes from pregnant rabbits. Biol. Reprod. 41, 587-603.

Levi, R., Burke, J.A., Guo, Z.-G., Hattori, Y., Hoppens, C.M., McManus, L.M., Hanahan, D.J. \& Pinckard, R.N. (1984) Acetyl glyceryl ether phosphorylcholine (AGEPC). A putative mediator of cardiac anaphylaxis in the guinea pig. Circ. Res. 54, 117-124.

Ludwig, J.C., Hoppens, C.L., McManus, L.M., Mott, G.E. \& Pinckard, R.N. (1985) Modulation of plateletactivating factor (PAF) synthesis and release from human polymorphonuclear leukocytes (PMN): role of extracellular albumin. Archs Biochem. Biophys. 241, 337-347.

Nakashima, S., Suganuma, A., Sato, M., Tohmatsu, T. \& Nozawa, Y. (1989) Mechanism of arachidonic acid liberation in platelet-activating factor stimulated human polymorphonuclear neutrophils. J. Immunol. 143, 1295-1302.

Niesert, S., Christopherson, W., Korte, K., Mitchell, M.D., MacDonald, P.C. \& Casey M.L. (1986) Prostaglandin $\mathrm{E}_{2}$ 9-ketoreductase activity in human decidua vera tissue. Am. J. Obstet. Gynecol. 155, 1348-1352.

Noyes, R.W., Hertig, A.T. \& Rock, J. (1950) Dating the endometrial biopsy. Fert. Steril. 1, 3-25.

O'Neill, C. (1985a) Examination of the causes of early pregnancy-associated thrombocytopenia in mice. $J$. Reprod. Fert. 73, 567-577.

O'Neill, C. (1985b) Partial characterization of the embryo-derived platelet-activating factor in mice. $J$. Reprod. Fert. 75, 375-380.

O'Neill, C. (1987) Embryo-derived platelet-activating factor: a preimplantation embryo mediator of maternal recognition of pregnancy. Domestic Anim. Endocrinology 4, 907-913.

O'Neill, C., Pike, I.L., Porter, R.N., Gidley-Baird, A.A., Sinosich, M.J. \& Saunders, F.M. (1985) Maternal recognition of pregnancy prior to implantation: methods for monitoring embryonic viability in vitro and in vivo. Ann. NY Acad. Sci. 442, 429-439.

O'Neill, C., Gidley-Baird, A.A., Pike, I.L. \& Saunders, F.M. (1987) Use of a bioassay for embryo-derived platelet-activating factor as a means of assessing quality and pregnancy potential of human embryos. Fert. Steril. 47, 969-975.
Orozco, C., Perkins, T. \& Clarke, F.M. (1986) Plateletactivating factor induces the expression of early pregnancy factor activity in female mice. J. Reprod. Fert. 78, 549-555.

Pauerstein, C.J., Eddy, C.A., Croxatto, H.D., Hess, R., Siler-Khodr, T.M. \& Croxatto, H.B. (1978) Temporal relationships of estrogen, progesterone, and luteinizing hormone levels to ovulation in women and infrahuman primates. Am. J. Obstet. Gynecol. 130, 876884.

Pinckard, R.N., Farr, R.S. \& Hanahan, D.J. (1979) Physicochemical and functional identity of rabbit platelet-activating factor (PAF) released in vivo during IgE anaphylaxis with PAF released in vitro from IgE sensitized basophils. J. Immunol. 123, 1847-1857.

Pinckard, R.N., Ludwig, J.C. \& McManus, L.M. (1988) Platelet-activating factors. In Inflammation: Basic Principles and Clinical Correlates, pp. 139-167. Eds J. I. Gallin, I. M. Goldstein \& R. Snyderman. Raven Press, New York.

Schatz, F., Markiewicz, L. \& Gurpide, E. (1987) Differential effects of estradiol, arachidonic acid, and A23187 on prostaglandin $F_{2 a}$ output by epithelial and stromal cells of human endometrium. Endocrinology 120, 1465-1471.

Schlegel, W., Krüger, S., Daniels, D., Fischer, B., Schneider, H.P.G. \& Beier, H.M. (1988) Studies on prostaglandin metabolism in corpora lutea of rabbits during pregnancy and pseudopregnancy. $J$. Reprod. Fert. 83, 365-370.

Shukla, S.D., Buxton, D.B., Olson, M.S. \& Hanahan, D.J. (1983) Acetylglyceryl ether phosphorylcholine. A potent activator of hepatic phosphoinositide metabolism and glycogenolysis. J. biol. Chem. 258, 1021210214

Smith, S.K. \& Kelly, R.W. (1987) The effect of the antiprogestins, RU 486 and ZK 98734, on the synthesis and metabolism of $\mathrm{PGF}_{2 a}$ and $\mathrm{PGE}_{2}$ in separated cells from early human decidua. $J$. clin. Endocrinol. Metab. 63, 527-537.

Smith, S.K. \& Kelly, R.W. (1988) Effect of plateletactivating factor on the release of PGF- $2 \alpha$ and PGE2 by separated cells of human endometrium. $J$. Reprod. Fert. 82, 271-276.

Snyder, F. (1989) Biochemistry of platelet-activating factor: a unique class of biologically active phospholipids. Proc. Soc. exp. Biol. Med. 190, 125-135.

Söling, H.-D., Eibl, H. \& Fest, W. (1984) Acetylcholinelike effects of 1-O-alkyl-2-acetyl-sn-glycero-3phosphocholine ('platelet-activating factor') and its analogues in exocrine secretory glands. Eur. $J$. Biochem. 144, 65-72.

Sueoka, K., Dharmarajan, A.M., Miyazaki, T., Atlas, S.J. \& Wallach, E.E. (1988) Platelet-activating factorinduced early pregnancy factor (EPF) activity from the perfused rabbit ovary and oviduct. Am.J. Obstet. Gynecol. 159, 1580-1584.

Tokumura, A., Fukuzawa, K. \& Tsukatani, H. (1984) Contractile effect of 1-O-hexadecyl-2-O-acetyl-snglycero-3-phosphocholine on strips of isolated rat intestine. J. Pharm. Pharmacol. 36, 210-212.

Whatley, R.E., Zimmerman, G.A., McIntyre, T.M. \& Prescott, S.M. (1988) Endothelium from diverse vascular sources synthesizes platelet-activating factor. Arteriosclerosis 8, 321-331. 
Wynn, R.M. (1989) The human endometrium. Cyclic and gestational changes. In Biology of the Uterus, 2nd edn, pp. 289-331. Eds R. M. Wynn \& W. P. Jollie. Plenum Medical Book Co., New York.

Yasuda, K., Satouchi, K. \& Saito, K. (1986) Plateletactivating factor in normal rat uterus. Biochem. Biophys. Res. Commun. 138, 1231-1236.
Yasuda, K., Satouchi, K., Nakayama, R. \& Saito, K. (1988) Acyl type platelet-activating factor in normal rat uterus determined by gas chromatography mass spectrometry. Biomed. Environ. Mass Spectrom. 16, 137-141.

Received 22 May 1990 